\title{
Sulphide 'mining' by lucinid bivalve molluscs: demonstrated by stable sulphur isotope measurements and experimental models
}

\author{
P. R. Dando ${ }^{1}$, S. A. Ridgway ${ }^{1, *}$, B. Spiro ${ }^{2}$ \\ 'Marine Biological Association of the United Kingdom, Citadel Hill, Plymouth PL1 2PB, United Kingdom \\ ${ }^{2}$ NERC Isotope Geosciences Laboratory, Kingsley Dunham Centre, Keyworth, Nottingham NG12 5GG, United Kingdom
}

\begin{abstract}
A profile of the isotopic composition, $\delta^{34} \mathrm{~S}$, of elemental sulphur, acid-labile sulphide, chromous-reducible sulphide and dissolved sulphate was recorded from $30 \mathrm{~cm}$ long cores taken from a sandy sediment at the low water mark at Mill Bay, a beach near the mouth of the Salcombe Estuary, SW England. The sediment is inhabited by the bivalve mollusc Lucinoma borealis, which has concentrations of elemental sulphur within endosymbiotic sulphur-oxidising bacteria in the gills. Sulphur from the gills was more depleted in ${ }^{34} \mathrm{~S}\left(\delta^{34} \mathrm{~S}=-38 \%\right)$ than any of the sulphur species within the sediment. The $\delta^{34} \mathrm{~S}$ of elemental sulphur in the sediment varied from $-19.5 \%$ at 0 to $5 \mathrm{~cm}$ depth to $-25.4 \%$ at 15 to $20 \mathrm{~cm}$ depth. The iron sulphides showed similar depth profiles for $\delta^{34} \mathrm{~S}$, from +6 to $+9 \%$ at 0 to $5 \mathrm{~cm}$ depth to -26 to $-29 \%$ at 15 to $20 \mathrm{~cm}$ depth. Interstitial dissolved sulphate showed an irregular profile, considerably depleted with respect to seawater sulphate, in the upper $3 \mathrm{~cm}\left(\delta^{34} \mathrm{~S}+15.8 \%\right)$ increasing with depth to $+20.1 \%$ at 18 to $23 \mathrm{~cm}$ depth and then decreasing to $+11.5 \%$ at 23 to $28 \mathrm{~cm}$. Model experiments on water pumping through permeable tubes of similar diameter to the inhalant tube of the bivalve illustrated the oxidative processes taking place around the inhalant tube and demonstrated the mobilisation of reduced sulphur from the iron sulphides in the sand that leads to highly depleted ${ }^{34} \mathrm{~S}$ in the gill. Results are discussed with respect to the nutritional strategies of lucinid bivalve molluscs.
\end{abstract}

KEY WORDS: Lucinoma borealis - Sulphur isotopes - Sulphide · Thiosulphate Nutrition

\section{INTRODUCTION}

In anoxic marine sediments the main sulphur mineralization process is bacterial sulphate reduction accompanied by sulphide precipitation. The large isotopic fractionation between the dissolved sulphate and the bacterially produced sulphide (Kaplan \& Rittenberg 1964) provides an indicator for following the diagenetic processes involved and is used in many models of the flux of sulphur species between the various reservoirs (Hartman \& Nielsen 1969, Goldhaber \& Kaplan 1974, Jørgensen \& Fenchel 1974).

The Salcombe Estuary, on the south coast of Devon, $\mathrm{UK}$, is a ria which has little freshwater input. Inside

\footnotetext{
- Present address: Dept of Zoology, Natural History Museum, Cromwell Road, London SW7 5BD, UK
}

the bar on the eastern shore, the sandy beach at Mill Bay is protected from extreme wave action by rocks to the south and Zostera beds to the west. These beds lie between the beach and the deep-water channel. The area of the beach from mean low water spring tides to the outer edge of the Zostera beds is the habitat of the bivalve mollusc Lucinoma borealis (L.). At this site $20 \%$ of the biomass between MLWS and ELWS is due to the bivalve, which has a mean density of 4 ind. $\mathrm{m}^{-2}$ (Dando et al. 1986). It burrows to a depth of 12 to $20 \mathrm{~cm}$ and uses its vermiform foot to form a inhalant tube, of approximately $1 \mathrm{~mm}$ diameter, up to the sediment surface so that oxygenated water can be drawn down to the gills (Allen 1958). The foot is also used to construct tunnels in the sediment below the animal. The sediment chemistry of the site at the south end of Mill Bay beach has previ- 
ously been described (Dando \& Southward 1986, Dando et al. 1986).

Lucinoma borealis obtains most of its nutrition from symbiotic chemoautotrophic sulphur-oxidising bacteria contained in specialised cells, bacteriocytes, in enlarged gills (Dando et al. 1986). The gills contain up to $0.1 \%$ elemental sulphur on a wet weight basis. This sulphur is located in the bacterial cells, in vesicles formed by invaginations of the periplasmic membrane. Similar sulphur deposits are found in the chemoautotrophic endosymbiotic bacteria of other bivalve species (Vetter 1985). The carbon fixed by the bacteria is incorporated into the body tissues of the bivalve (Spiro et al. 1986).

Within the depth range of the tunnels constructed by the bivalve, the upper 30 to $40 \mathrm{~cm}$ of sediment, there are only very low concentrations of soluble reduced sulphur species, $<5 \times 10^{-7} \mathrm{~mol} \mathrm{dm^{-3 }}$ sediment, in expressed interstitial water (Dando et al. 1986). This situation is common in many other sediments inhabited by shallow water bivalve molluscs with endosymbiotic sulphur-oxidising bacteria (Dando et al. 1985, Spiro et di. 1986). It is believed that the bivalves may obtain reduced sulphur species for the bacteria by local partial oxidation of the iron sulphides in the sediment close to the permeable inhalant tubes constructed with the foot.

Evidence for this 'mining' of the insoluble reduced sulphur species in the sediment is provided by the observations for Lucinoma borealis (Dando et al. 1986), Myrtea spinifera (Dando et al. 1985) and for Thyasira flexuosa and T. sarsi (Dando \& Southward 1986) that the sediment surrounding the inhalant tube is oxidised. $L$. borealis and $M$. spinifera changed the position of the inhalant tubes every few days so that eventually, in tank studies in which fresh organic input to the sediment was excluded, a cone of oxidised sand was formed above the bivalve. The bivalve is located in the sediment below the most active zone of sulphate reduction, which is within the upper $10 \mathrm{~cm}$ of sediment (Dando et al. 1986). The elemental sulphur deposits in the gill bacteria reach a maximum in September, coinciding with the maximum sulphate reduction rate and acid-labile sulphide concentrations in the sediment. When the animal is removed from the sediment the sulphur is oxidised within a few days.

There is thus a rapid cycling of sulphur between sulphate and sulphide in the upper $20 \mathrm{~cm}$ of sediment due to the activities of the bivalve and to tidal effects. The present study aimed to investigate the source of the reduced sulphur reservoir used by the bivalves by a study of sulphur isotope ratios and by setting up a model system to mimic the activity of the bivalves in pumping water through their inhalant tubes.

\section{MATERIALS AND METHODS}

The sample site was described by Dando et al. (1986). Samples were taken in February at the southern end of the beach at Mill Bay, just inside the Zostera beds at ELWS; the sediment temperature at the time of sampling was $5.0^{\circ} \mathrm{C}$. Sediment cores were taken in glass fibre tubes of $50 \mathrm{~mm}$ internal diameter, which were pushed into the sediment by hand within a few cm of each other. The cores were sealed with bungs and subsequently handled in a glove bag in an atmosphere of argon. Sand in the upper 5 to $5.5 \mathrm{~cm}$ was yellow and visibly oxidised. Core samples were cut into $5 \mathrm{~cm}$ long segments for analysis.

Elemental sulphur was extracted, from combined samples taken from 5 cores, by shaking the sediment with chloroform in an atmosphere of argon. Chloroform was removed by rotary evaporation and the residue was redissolved in hexane. The sulphur was separated from extracted lipids by chromatography of the extract on a column of alumina eluted with hexane. After evaporating to dryness, the sulphur fraction was dissolved in acetone and the solution gently evaporated under nitrogen until yellow crystals of sulphur started to form.

Acid-labile sulphide was obtained from the chloroform-extracted sediment by treating it with $50 \%$ hydrochloric acid under a stream of argon and collecting the hydrogen sulphide released in traps containing $(5 \% \mathrm{w} / \mathrm{v})$ zinc acetate solution. Following this treatment the sediment was reduced with chromous chloride (Zhabina \& Volkov 1978) and the hydrogen sulphide released was similarly trapped. This sulphide will contain the pyrite sulphur together with a little elemental sulphur produced from FeS during the acidification step. A parallel core was pressed under nitrogen and the interstitial water collected after passing through a cellulose acetate filter of $0.2 \mu \mathrm{m}$ porosity. Sulphate was precipitated as the barium salt.

Two parallel cores were sectioned as above and the combined sediment from the different horizons was diluted with degassed seawater and bubbled with argon. The gas was subsequently passed through a zinc acetate trap to collect any free sulphide present; no sulphide was collected.

Gills were dissected from 21 Lucinoma borealis, of shell lengths between 10.1 and $34.2 \mathrm{~mm}$, within $2 \mathrm{~h}$ of collection. The gills had a combined wet weight of $2.58 \mathrm{~g}$. They were rinsed several times in filtered seawater and fixed in a solution of $4 \%(\mathrm{v} / \mathrm{v})$ formaldehyde and $2 \%(\mathrm{w} / \mathrm{v})$ cadmium chloride. After homogenisation they were extracted with chloroform and the elemental sulphur was purified as for the sediment extract 
Sulphide samples were prepared for sulphur isotope analysis following the method of Robinson \& Kusakabe (1975). The barium sulphate was prepared for analysis according to Coleman \& Moore (1978). Analyses were performed in a VG SIRA 10 mass spectrometer. Results are reported in the $\delta$ notation as \%o deviation from the Canyon Diablo Triolite standard. The total analytical reproducibility was $0.1 \%$.

A semipermeable tube of polysulphone, $455 \mathrm{~mm}$ long, $1 \mathrm{~mm}$ i.d., with a pore size of $7 \mu \mathrm{m}$ (Supelco Inc., Bellefonte, PA, USA) was connected to PTFE tubing at either end and buried vertically in a sample of sediment, taken from the habitat of another lucinid bivalve, Loripes lucinalis. It was placed such that the permeable tube was below the redox potential discontinuity, approximately $5 \mathrm{~cm}$ below the sediment surface. One piece of the connecting tubing was connected to a peristaltic pump, while the other end was left free above the sediment. The sediment was covered in seawater and the tank containing the seawater was covered to prevent evaporation. The polysulphone tubes were filled with seawater and left for $2 \mathrm{wk}$ for the disturbed sediment to equilibrate. At the start of an experiment a sample of water in the permeable tube, which should have reached equilibrium with the interstitial water, was withdrawn by attaching a glass microsyringe to the free end of the tube. An initial volume, equivalent to the dead volume of the PTFE tube, was discarded. The water from the permeable tube was immediately treated with monobromobimane at $\mathrm{pH} 8.0$ to form derivatives with sulphide, thiosulphate and sulphite (Newton et al. 1981). The derivatives were separated by HPLC on a Spherisorb ODS-2 column and detected by fluorescence. After this initial sampling, oxygenated seawater, which had been filtered through a cellulose acetate membrane of $0.2 \mu \mathrm{m}$ porosity, was pumped through the semipermeable tube, at intervals, with a flow rate of 0.22 or $0.4 \mathrm{ml}$ $\mathrm{min}^{-1}$. Samples of both the inflowing and the outflowing water were examined for concentrations of sulphide, thiosulphate and sulphite as before. After stopping the water flow samples were again withdrawn for testing, after discarding the dead volume, $50 \mu \mathrm{l}$, in the PTFE connecting tubing.

Lucinoma borealis were observed in the laboratory by keeping them in tall glass tanks, of $3 \mathrm{~cm}$ cross section, the sides of which were covered by black slides. These tanks were filled with black, reducing sediment from the study site and immersed in larger tanks of running seawater. Either 1 or 2 bivalves were placed in each tank of sediment and allowed to burrow. The glass tanks of sediment were removed from the seawater tank at intervals and the slides were lifted for observation of the tunnel systems constructed by the bivalves.

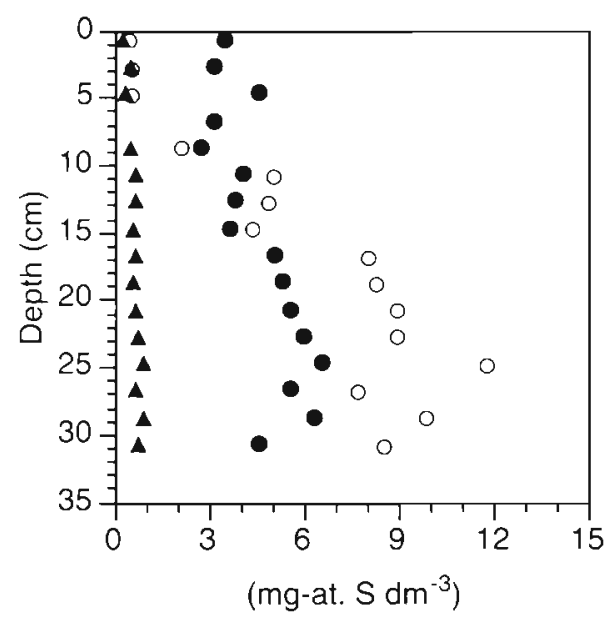

Fig. 1. Sediment depth profiles, in November, of elemental sulphur ( $\Delta$ ), acid-labile sulphide $(0)$ and chromous-reducible sulphide ( ) from the intertidal habitat of Lucinoma borealis at Mill Bay, Devon, UK

\section{RESULTS}

A typical sediment profile from the Lucinoma borealis habitat at Mill Bay, inside the Zostera beds, for elemental sulphur, acid-labile sulphide and chromousreducible sulphide is shown in Fig. 1. The cores sampled for sulphur isotopes were $30 \mathrm{~cm}$ long. They were sampled for dissolved sulphate down to $28 \mathrm{~cm}$ and for elemental sulphur, acid-labile sulphide and pyrite down to $20 \mathrm{~cm}$. One sample of elemental sulphur was analysed from $L$. borealis gill extracts. The $\delta^{34} \mathrm{~S}$ results are depicted in Fig. 2. All reduced sulphur species showed a steady decrease in $\delta^{34} \mathrm{~S}$ with depth. Elemental sulphur was the most ${ }^{34} \mathrm{~S}$-depleted species

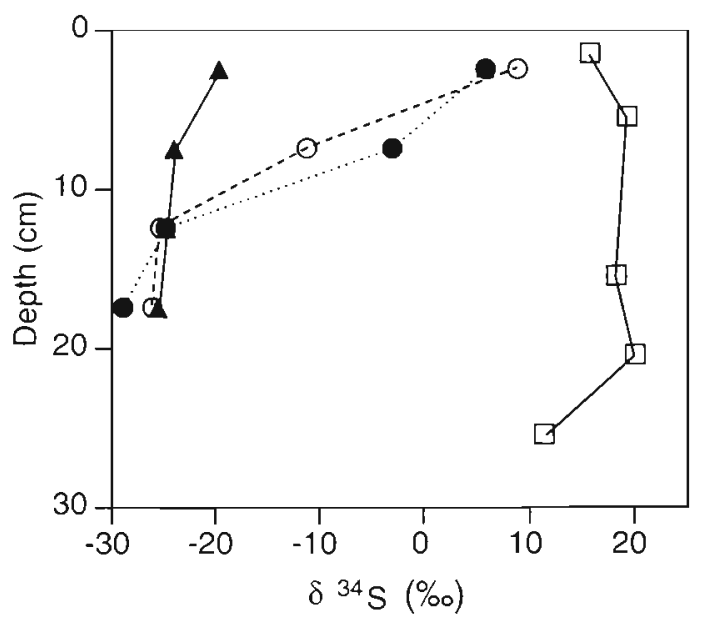

Fig. 2. Changes in $\delta^{34} \mathrm{~S}(\%)$ with sediment depth for: interstitial sulphate $(\square)$, elemental sulphur $(\boldsymbol{\Lambda})$, acid-labile sulphide (O) and chromous-reducible sulphide (O) 


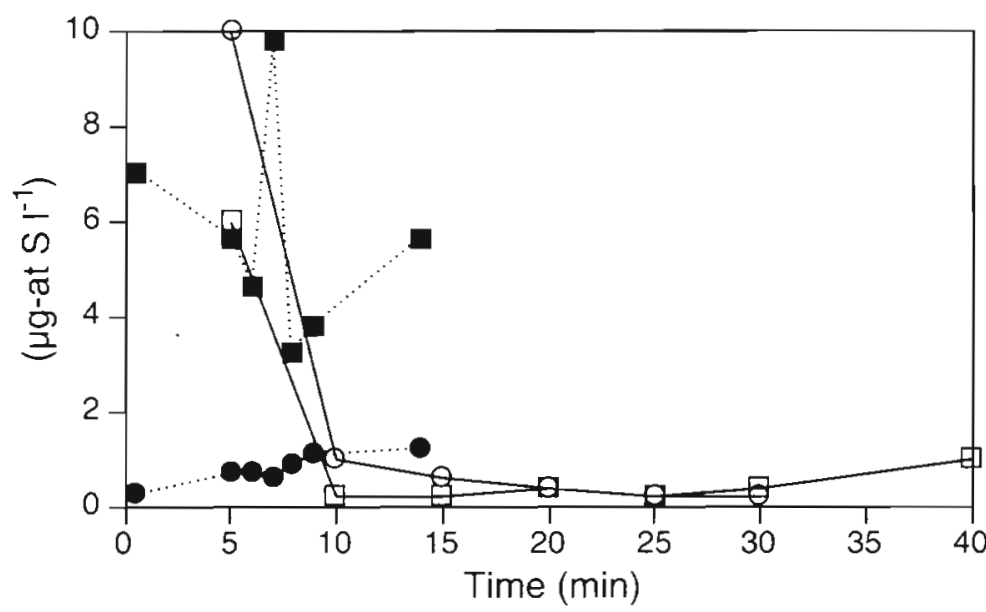

Fig. 3. Sulphide $(O, \bullet)$ and thiosulphate $(\square, \mathbf{\square})$ concentrations in water flowing out of semipermeable tubes under the described conditions: ( - ) first experiment, continuous flow of $0.4 \mathrm{ml} \mathrm{min}^{-1}$ for $30 \mathrm{~min}_{\text {; }}(\ldots$.$) second$ experiment, using a pulsed flow of $0.22 \mathrm{ml} \mathrm{min}^{-1}$ concentrations which increased from 0.3 to $1.2 \mu \mathrm{g}$-at. $\mathrm{S}^{-1}$. The water volumes and sulphur species concentrations were too low for sulphur isotope analysis.

Tank observations on Lucinoma borealis placed in black iron sulphide-rich sediment from Mill Bay showed that over a period the bivalves constructed, using their elongated foot, inhalant tubes at angles from the bivalve up to the sediment surface, such that after some months a cone of sediment from the bivalve up to the surface was oxidised to yellow sand. This was done by the drawing down of oxygenated surface water through the inhalant tubes. There was no indication that the position of the bivalves near the bottom of the experimental tank changed from the position they had taken after initial burrowing.

\section{DISCUSSION}

close to the surface and showed the smallest change with depth. Acid-labile and chromous-reducible sulphides had similar profilies; in relation to the $\delta^{34} \mathrm{~S}$ of $\mathrm{S}^{\circ}$ they were more than $20 \%$ heavier in the 0 to $5 \mathrm{~cm}$ horizon and were slightly more depleted than $\mathrm{S}^{\circ}$ in the 15 to $20 \mathrm{~cm}$ horizon. Dissolved sulphate differed in behaviour, increasing from $+15.9 \%$ near the surface to $+20.1 \%$ at 18 to $23 \mathrm{~cm}$ depth and then decreasing to $+11.5 \%$ at 23 to $28 \mathrm{~cm}$. The elemental sulphur in the bivalve gills was the most ${ }^{34} \mathrm{~S}$-depleted form of all with a $\delta^{34} \mathrm{~S}$ of $-38 \%$.

In the model experiment on the effect of pumping water through a tube resembling the semipermeable inhalant tube of the bivalve, the filtered seawater used for pumping through the tube showed no detectable reduced sulphur species, i.e. $<0.05 \mu \mathrm{g}$-at. $\mathrm{S}^{-1}$, and no reduced sulphur species could be detected in the initial water in the semipermeable tube. Outflowing water, sampled after the flow of oxygenated seawater through the tube had started, had concentrations of thiosulphate and sulphide in the range 0.2 to $10.0 \mu \mathrm{g}$-at. S $\mathrm{l}^{-1}$ (Fig. 3). For the first experiment a continuous flow rate of $0.4 \mathrm{ml} \mathrm{min} \mathrm{m}^{-1}$ over $30 \mathrm{~min}$ was used, with sampling every $5 \mathrm{~min}$. The first sample showed high values of $6.0 \mu \mathrm{g}$-at. $\mathrm{S}^{-1}$ for thiosulphate and $10.0 \mu \mathrm{g}$-at. $\mathrm{S}^{-1}$ for sulphide; these then decreased to between 0.2 and $0.4 \mu \mathrm{g}$-at. $\mathrm{S} \mathrm{I}^{-1}$ and $0.2 \mu \mathrm{g}$-at. S $\mathrm{I}^{-1}$ respectively after 25 to $30 \mathrm{~min}$. After $10 \mathrm{~min}$ with no pumping a final sample was taken which showed a small increase in both sulphide and thiosulphate. In a second experiment a pulsed pumping rate of $0.22 \mathrm{ml}$ min $^{-1}$ was used. Water was pumped through the tube for $1 \mathrm{~min}$ every $5 \mathrm{~min}$ and samples were taken $0.5 \mathrm{~min}$ after pumping stopped. This gave higher thiosulphate concentrations of 3.2 to $4.9 \mu \mathrm{g}$-at. $\mathrm{S} \mathrm{l}^{-1}$ and sulphide
A change of isotope ratios with depth, in both reduced and oxidised sulphur species, normally results from sulphate reduction and the consequent increased concentration of reduced sulphur species and corresponding decrease in sulphate. Depending on the nature of the system, closed or open to sulphate, their isotopic composition may or may not show a depthrelated $\delta^{34} \mathrm{~S}$ profile. The expectation was that tidal pumping of water through the sediment at this site would result in rapid replenishment of sulphate and hence little change in the isotope ratios for a given sulphur species with depth.

Interstitial sulphate close to the sediment surface $(+15.8 \%)$ was depleted in ${ }^{34} \mathrm{~S}$ relative to open seawater $(+20 \%)$. Thus even in the upper $3 \mathrm{~cm}$ of sediment there must be a significant contribution to the sulphate from oxidation of reduced and fractionated sulphur. Since care was taken to prevent oxidation during sample preparation these relatively low values can be regarded as a true representation of the interstitial sulphate. It is also interesting that the depth profile of sulphate does not follow the expected trend of becoming isotopically heavier with depth due to a progressive fractionation during sulphate reduction, such as recorded in recent anoxic sediments in Kiel Bay (Hartman \& Nielsen 1969) and San Pedro Martir Basin, Gulf of California (Zak et al. 1980). Similar ${ }^{34} \mathrm{~S}$ profiles for interstitial sulphate were found by Kaplan et al. (1963) in the Santa Monica Basin sediments and in the intertidal Newport Marsh sediments in California. We may have a cycle in the sediment with enrichment of the sulphate in ${ }^{32} \mathrm{~S}$ during spring tides when oxygen is drawn into the sediment and the sulphides are oxi- 
dised and enrichment in ${ }^{34} \mathrm{~S}$ during neap tides when none of the sediment is exposed. The present sample was collected during spring tides. Another factor at this site is the occasional mixing of sediment horizons by erosion and redeposition during periods of southerly gales and strong tides.

The acid volatile sulphides, greigite and mackinawite, are the first metal sulphides to form (Harmsen et al. 1954, Kaplan et al. 1963) and their isotopic composition on formation reflects that of the dissolved sulphide. This is well documented for the upper part of core 50G from the Pescadero Basin (Kaplan et al. 1963). In the present core the lower samples, with a $\Delta^{34} \mathrm{~S}_{\mathrm{SO}_{4} \text {-FeS }}$ of approximately $-40 \%$, agree with the difference reported in cultures of sulphate-reducing bacteria utilising organic matter at low reduction rates (Chambers \& Trudinger 1980). The upper part of the core has a lower $\Delta^{34} \mathrm{~S}$ which would agree with the higher sulphate reduction rates observed for this part of the sediment (Dando et al. 1986). The large difference between the $\delta^{34} \mathrm{~S}$ for elemental sulphur and acid-labile sulphide in the upper $10 \mathrm{~cm}$ of sediment shows that isotope exchange between these species must be very slow in this sediment, probably as a result of low $\mathrm{HS}^{-}$and polysulphide concentrations (Fossing \& Jørgensen 1990a). Isotope exchange between $\mathrm{FeS}_{2}$ and other sulphur species was not found by these authors.

Pyrite may be formed from the monosulphide precursors by reaction with elemental sulphur (Goldhaber \& Kaplan 1974). Since elemental sulphur is much more depleted in ${ }^{34} \mathrm{~S}$ than the acid-labile sulphides in the upper $10 \mathrm{~cm}$ this would lead to the pyrite-S also being more depleted than the sulphur in the acid-labile sulphides, as found. Oxidation of both elemental sulphur and pyrite leads to ${ }^{34} \mathrm{~S}$ depletion of 1 to $2 \%$ in the sulphate produced with consequent enrichment of ${ }^{34} \mathrm{~S}$ in the residual pyrite (Nakai \& Jensen 1964). Since oxidation, due to tidal and bivalve pumping and sediment bioturbation, will decrease with increasing sediment depth this should also result in a slight decrease of ${ }^{34} \mathrm{~S}$ in pyrite with depth.

Unexpectedly, the elemental sulphur in the bivalve gills was more depleted in ${ }^{34} \mathrm{~S},-38 \%$, than any of the sulphur species measured in the sediment. It was over $12 \%$ more depleted than the elemental sulphur and over $9 \%$ more depleted than the pyrite in any of the sediment horizons examined. The sulphur extracted from the gills of 2 other bivalve species containing sulphur-oxidising endosymbiotic bacteria, Calyptogena soyae and Solemya velum, showed less depletion with $\delta^{34} \mathrm{~S}$ values of $-28 \%$ (Conway et al. 1988, Hashimoto et al. 1989). In the case of $C$. soyae this value was similar to that of the sulphur extracted from the surrounding sediment.
The model experiment demonstrated that, in the absence of added oxygen, the concentrations of dissolved sulphide, thiosulphate and sulphite in the permeable tube are below the limits of detection $(<0.05 \mu \mathrm{M})$ as had previously been reported for the Mill Bay sediment (Dando et al. 1986). Slow pumping of oxygenated seawater through the permeable tube resulted in an outflow of water containing sulphide and thiosulphate, but no detectable sulphite. The thiosulphate would be expected to result from chemical oxidation of the iron sulphides in the sediment (Goldhaber 1983) and the sulphide from disproportionation of thiosulphate by sulphate-reducing bacteria in the sediment (Jørgensen 1990).

The outer $\mathrm{S}$, sulphane, atom of thiosulphate is depleted in ${ }^{34} \mathrm{~S}$ relative to the inner $\mathrm{S}$, sulphonate (Uyama et al. 1985, Fry et al. 1986). In oxidised surface sediment most of the thiosulphate, formed by partial oxidation of the elemental sulphur or iron sulphides, is disproportionated to sulphide and sulphate: the ${ }^{34} \mathrm{~S}$ depleted outer atom is converted to sulphide (Fossing \& Jørgensen 1990b, Jørgensen 1990). Disproportionation of thiosulphate can involve large kinetic isotope effects, of the order of $20 \%$, with the sulphide formed becoming isotopically light, relative to the sulphate (Agarwala et al. 1965). It is known that the bacteria in Lucinoma borealis gills can utilise sulphide (Dando et al. 1986). Their ability to oxidise thiosulphate is unknown. Utilisation of the sulphide, resulting from thiosulphate disproportionation, by the endosymbiotic bacteria in the gills of $L$. borealis would account for the large ${ }^{34} \mathrm{~S}$-depletion observed in the gill elemental sulphur.

Another strategy that may be employed by some Lucinoma borealis is to extract dissolved sulphide from local pockets of decaying organic matter in the sediment below the animal. Small pockets of decaying seaweed in the habitat do smell of hydrogen sulphide, although a definite association of $L$. borealis with these patches has not been noted. It is possible that the sulphide produced deeper in the sediment, below the animal, may be more depleted in ${ }^{34} \mathrm{~S}$, although we have no evidence for this. This second strategy has been described for the related species $L$. aequizonata from the Santa Barbara Basin, California (Cary et al. 1989). $L$. aequizonata however burrows very shallowly, 2 to $5 \mathrm{~cm}$, and constructs tunnels more extensively into the sediment below the animal than does $L$. borealis, suggesting an adaptation to the utilisation of these buried pockets.

We believe that Lucinoma borealis, and similar species, are able to exploit, 'mine', the insoluble sulphides in the sediment by means of constructing new semipermeable inhalant tubes at frequent intervals and oxidising fresh sediment by pumping water through 
the tube. Disproportionation of the thiosulphate formed by chemical oxidation results in dissolved sulphide which diffuses into the inhalant tube where it is carried to the sulphur-oxidising bacteria in the gills. This mechanism explains the exceptionally high ${ }^{34} \mathrm{~S}$-depletion observed in the elemental sulphur in $L$. borealis gills relative to the reduced sulphur species in the sediment. Long-term observations on thyasirids in Gullmarfjord demonstrate that they have a major impact on oxidation of iron sulphides in the sediment (Dando \& Spiro 1993) and a similar influence may be expected for lucinids. These effects of the oxidation of sulphide minerals, without apparent bioturbation, may provide an additional factor in explaining the large range of $\delta^{34} \mathrm{~S}$ in sedimentary pyrite from marine sediments, particularly since similar oxidative effects, due to the presence of gutless pogonophores with endosymbiotic sulphur-oxidising bacteria, may be observed down to sediment depths of $0.5 \mathrm{~m}$ or more (Southward \& Dando 1988).

Acknowledgements. We thank Roger Ling for assistance at the MBA. This study was funded in part by the EC under MAST programme contract 0044 C. S.A.R. was supported by the Leverhulme Trust, as a component of an institutional grant to the MBA for studies on the evolution of symbiosis between marine invertebrates and symbiotic bacteria.

\section{LITERATURE CITED}

Agarwala, L., Ress, C. H., Thode, H. G. (1965). Sulfur isotope effect in the hydrogen ion decomposition of thisosulfate. Can. J. Chem. 43: 2801-2811

Allen, J. A. (1958). On the basic form and adaptations to habitat in the Lucinacea (Eulamellibranchia). Phil. Trans. R. Soc. Lond. B 241: 421-484

Cary, S. C., Vetter, R. D., Felbeck, H. (1989). Habitat characterization and nutritional strategies of the endosymbiontbearing bivalve Lucinoma aequizonata. Mar. Ecol. Prog. Ser. 55: 31- 45

Chambers, L. A., Trudinger, P. A. (1980). Microbiological fractionation of stable sulphur isotopes: a review and critique. Geomicrobiol. J. 1: 249-293

Coleman, M. L., Moore, M. P. (1978). Direct reduction of sulphate to sulphur dioxide for isotopic analysis. Analyt. Chem. 50: $1594-1595$

Conway, N., Capuzzo, J. M., Fry, B. (1988). The role of endosymbiotic bacteria in the nutrition of Solemya velum: evidence from a stable isotope analysis of endosymbionts and host. Limnol. Oceanogr. 34: 249-255

Dando, P. R., Southward, A. J (1986). Chemoautotrophy in bivalve molluscs of the genus Thyasira. J. mar. biol. Ass. U.K. 66: 915-929

Dando, P. R., Southward, A. J., Southward, E. C. (1986). Chemoautotrophic symbionts in the gills of the bivalve mollusc Lucinoma borealis and the sediment chemistry of its habitat. Proc. R. Soc. Lond. B 227: 227-247

Dando, P. R., Southward, A. J., Southward, E. C., Terwilliger, N. B., Terwilliger, R. C. (1985). Sulphur-oxidising bacteria and haemoglobin in gills of the bivalve mollusc Myrtea spinifera. Mar. Ecol. Prog. Ser. 23: 85-98

Dando, P. R., Spiro, B. (1993). Varying nutritional dependence of the thyasirid bivalves Thyasira sarsi and $T$. equalis on chemoautotrophic symbiotic bacteria, demonstrated by isotope ratios of tissue carbon and shell carbonate. Mar. Ecol. Prog. Ser. 92: 151-158

Fossing, H., Jørgensen, B. B. (1990a). Isotope exchange reactions with radiolabelled sulphur compounds in anoxic seawater. Biogeochem. 9: 223-245

Fossing, H., Jørgensen, B. B. (1990b). Oxidation and reduction of radiolabelled inorganic sulphur compounds in an estuarine sediment, Kysing fjord, Denmark. Geochim. Cosmochim. Acta 54: 2731-2742

Fry, B., Cox, J., Gest, H., Hayes, J. M. (1986). Discrimination between ${ }^{34} \mathrm{~S}$ and ${ }^{32} \mathrm{~S}$ during bacterial metabolism of inorganic sulphur compounds. J. Bact. 165: 328-330

Goldhaber, M. B. (1983). Experimental study of metastable sulphur oxyanion formation during pyrite oxidation at pH 6.9 and $30^{\circ} \mathrm{C}$. Am. J. Sci. 283: 193-217

Goldhaber, M. B., Kaplan, I. R. (1974). The sulphur cycle. In: Goldberg, E. D. (ed.) The sea, Vol. 5. John Wiley, London, p. 569-655

Harmsen, G. W., Quipsel, A., Otzen, D. (1954). Observations on the formation and oxidation of pyrite in the soil. Pl. Soil 5: $324-348$

Hartman, M. von, Nielsen, H. (1969). $\delta^{34}$ S-Werte in rezenten Meeressedimenten und ihre Deutung an Beispiel einiger Sedimentprofile aus der westlichen Ostsee. Geol. Rundschau 58: 621-655

Hashimoto, I., Ohta, S., Tanaka, T : Hotta. H., Matsuzawa, S. Sakai, H. (1989). Deep-sea communities dominated by the giant clam, Calyptogena soyae, along the slope foot of Hatsusuima Island, Sagami Bay, Central Japan. Palaeogeog. Palaeoclimatol. Palaeoecol. 71: 179-192

Jørgensen, B. B. (1990). A thiosulphate shunt in the sulphur cycle of marine sediments. Science 249: 152-154

Jørgensen, B. B., Fenchel, T (1974). The sulphur cycle of a marine sediment model system. Mar. Biol. 24: 189-201

Kaplan, I. R., Emery, K. O., Rittenberg, S. C. (1963). The distribution and isotopic abundance of sulphur in recent marine sediments off southern California. Geochim. Cosmochim. Acta 27: 297-331

Kaplan, I. R., Rittenberg, S. C. (1964). Microbiological fractionation of sulfur isotopes. J. gen. Microbiol. 34: 195-212

Nakai, N., Jensen, M. L. (1964). The kinetic isotope effect in the bacterial reduction and oxidation of sulphur. Geochim. Cosmochim. Acta 28: 1893-1912

Newton, G. L., Dorian, R., Fahey, R. C. (1981). Analysis of biological thiols: derivatization with monobromobimane and separation by reverse-phase high performance liquid chromatography. Analyt. Biochem. 114: 383-387

Robinson, B. W., Kusakabe, N. (1975). Quantitative preparation of sulphur dioxide for $32 \mathrm{~S} / 34 \mathrm{~S}$ analysis from sulphides by combustion with cuprous oxide. Analyt. Chem. 47: $1179-1181$

Southward, A. J., Dando, P. R. (1988). Distribution of Pogonophora in canyons of the Bay of Biscay: factors controlling abundance and depth range. J. mar. biol. Ass. U.K. 68: $627-638$

Spiro, B., Greenwood, P. B., Southward, A. J., Dando, P. R. (1986). ${ }^{13} \mathrm{C} /{ }^{12} \mathrm{C}$ ratios in marine invertebrates from reducing sediments: confirmation of nutritional importance of chemoautotrophic endosymbiotic bacteria. Mar. Ecol. Prog. Ser. 28: 233-240

Uyama, F., Chiba, H., Kusakabe, M., Sakai, H. (1985). Sulfur isotope exchange reactions in the aqueous system: thiosulphate-sulfide-sulfate at hydrothermal temperature. Geochem. J. 19: 301-315

Vetter, R. D. (1985). Elemental sulfur in the gills of three spe- 
cies of clams containing chemoautotrophic symbiotic bacteria: a possible inorganic energy storage compound. Mar Biol. 88: 33-42

Zak, I., Sakai, H., Kaplan, I. R. (1980). Factors controlling the ${ }^{18} \mathrm{O} /{ }^{16} \mathrm{O}$ and ${ }^{34} \mathrm{~S} /{ }^{32} \mathrm{~S}$ isotope ratios of ocean sulfates, evaporites and interstitial sulfates from modern deep sea sediments. In: Goldberg, E. D., Horibe, Y., Saruhashi, K. (eds.)

This article was presented by A. J. Southward, Plymouth, UK
Isotope marine chemistry. Uchida Rokakuho Publishing Co., Tokyo, p. 339-373

Zhabina, N. N., Volkov, I. I. (1978). A method of determination of various sulphur compounds in sea sediments and rocks. In: Krumbein, W. E. (ed.) Environmental biogeochemistry and geomicrobiology, Vol. 3. Ann Arbor Science Publishers, Ann Arbor, p. 735-746

Manuscript first received: November 15, 1993

Revised version accepted: February 8, 1994 